\title{
Diagnosis: Laboratorial Investigation and Imaging Methods
}

\author{
José Fernando Vilela-Martin and Luciana Neves Cosenso-Martin \\ State Medical School of São José do Rio Preto (FAMERP), São Paulo, \\ Brazil
}

\section{Introduction}

Pheochromocytomas and paragangliomas are rare catechomine-producing tumors. Pheochromocytoma is a chromaffin tumor originating in the adrenal medulla and paraganglioma is originating in the sympathetic and parasympathetic portions of the autonomic nervous system paraganglia. The patients' symptoms are variable according the tumor secretion of norepinephrine (NE), epinephrine (E) or dopamine into the circulation. Patients with tumors predominantly secrete norepinephrine present with severe and refractory hypertension to conventional treatment. Patients with predominantly epinephrine and dopamine-secreting tumors present with episodic symptoms such as tachycardia with palpitations, panic attacks and feelings of doom.

\subsection{Multiple Endocrine Neoplasia syndromes (MEN)}

MEN 1 is a rare autosomal dominant disease that consists of tumors of the parathyroid glands, pancreatic islets (insulinomas) and anterior pituitary. Pheochromocytoma is not a feature in this syndrome.

MEN 2 is an autosomal dominant syndrome with three recognized sub-types: MEN 2A, B and C. In MEN 2A (Sipple's syndrome), medullary thyroid carcinoma is associated with pheochromocytoma and hyperparathyroidism. Pheochromocytoma is frequently bilateral and the diagnosis is later than medullary carcinoma. Patients who have been treated for medullary carcinoma should be screened for pheochromocytoma.

\section{Epidemiology}

The prevalence of pheochromocytoma is not precisely known. However, the incidence is about 1-2 per 100,000 adults per year according study in Minnesota (Beard et al., 1983). In countries other than United States, a lesser incidence has been noted about 2 to 8 cases per million inhabitants per year (Stenström \& Svärdsudd, 1986). In a large series of patients screened biochemically for suspicion of pheochromocytoma, the incidence has been described to be as high as $1.9 \%$. There was no difference between men and women (Smythe et al., 1992). Recently, a clinical review described the incidence between 2 and 8 cases per million per year in the United States (Golden et al., 2009). In an autopsy series described by McNeil et al. one pheochromocytoma occurred per 2301 autopsies (McNeil et al., 2000). With the routine use of computerized tomography (CT) for abdominal complaints, it is likely that 
more tumors will be discovered. The tumor is discovered incidentally in approximately $10 \%$ of patients during CT or magnetic resonance imaging (MRI) of the abdomen for unrelated symptoms (Kudva et al., 2003). However, recently others authors reported a 30\% rate of incidentally discovered pheochromocytomas in their cohort of patients (Kopetschke et al., 2009; Shen et al., 2010). Pheochromocytoma is present in $0.1 \%$ to $1 \%$ of patients with hypertension (Omura et al., 2004)

Approximately $10 \%$ of adrenal pheochromocytomas and $30 \%$ of paragangliomas are considered malignant (Suh et al., 2009). $70 \%$ to $80 \%$ of pheochromocytomas occur sporadically. The familial syndromes that may present with pheochromocytoma include multiple endocrine neoplasia type 2 (NEM 2), von Hippel-Lindau syndrome, Osler-WeberRendu syndrome, and neurofibromatosis syndrome type 1 (Guerrero et al., 2009). The peak incidence occurs in the third to fifth decades of life and the average age at diagnosis is 43.9 years in sporadic cases (Neumann et al., 2002). However, the familial syndromes include younger patients (24.9 years), extra-adrenal and multiple tumors and the hypertension is persistent (Perel et al., 1997). Some authors studied genetic screening in pheochromocytoma and found younger patients with familial syndromes in their cohorts (Manelli et al., 2009; Cascon et al., 2009).

Pheochromocytoma was the most frequent indication for adrenalectomy (23.2\%) noted by Villar (Villar et al., 2010).

The $10 \%$ rule is no longer applied. The ectopic pheochromocytoma is more prevalent than $10 \%$ (Madani et al., 2007). Extra-adrenal tumors are extra-adrenal paragangliomas and the majority is located in the head and neck area (69\%), followed by intra-abdominal (22\%) and intrathoracic locations (10\%) (Van Der Horst-Schrivers et al., 2010). The periaortic, pericaval regions and Zuckerkandl's were the commonest sites of abdominal paragangliomas (Erickson et al., 2001).

\section{Pathophysiology}

\subsection{The sympathetic nervous system (SNS)}

The hypertension of pheochromocytoma has been thought to result solely from the action of circulating catecholamines on cardiovascular adrenergic receptors. However, according to the studies of Bravo et al., blood pressure demonstrates no correlation with circulating catecholamines (Bravo et al., 1979). Bravo and collaborators related that sympathetic reflexes are intact, and blood pressure and heart rate are significantly reduced by clonidine despite maintained high circulating catecholamine (Bravo et al., 1982).

In pheochromocytoma patients, the SNS activity is enhanced and maintains the elevated blood pressure by the catecholamine-induced hypertension. The paradoxical elevation of sympathetic activity during elevation of circulating catecholamine is postulated to be due three mechanisms: 1) loading of sympathetic vesicles with catecholamine, presumably reflecting a loading of noradrenergic terminal vesicles with neurotransmitter; 2) increased sympathetic neuronal impulse frequency; and 3) a selective desensitization of presynaptic $\mathrm{a}_{2}$ -adrenergic receptors. These receptors inhibit release of neuronal NE. Thus, selective desensitization results in enhanced release of neuronal NE during nerve stimulation.

The hypertensive crisis could be produced by any direct or reflexly mediated stimulus to the SNS, because of the enhanced SNS activity and excessive stores of NE in sympathetic nerve terminals (Bravo \& Tagle, 2003). 


\subsection{The neurohumoral agents}

Angiotensin II has no direct role in pheochromocytoma, because the administration of clonidine reduces arterial blood pressure without significantly decreasing plasma renin activity (Bravo et al., 1982). Neuropeptide Y (NPY) levels are increased in plasma and in tumors of patients with pheochromocytoma (deS Senanayake et al., 1995; Lundberg et al., 1986). NPY increases coronary and peripheral and vascular resistance independently of aadrenergic mechanisms by interacting with vascular $G$ protein-coupled receptors ( $\mathrm{O}^{\prime}$ Hare \& Schwartz, 1989; Lundberg et al., 1982). The hypertensive episodes that occur in pheochromocytoma patients receiving a-blockade might be due the NPY release by the pheochromocytoma.

\subsection{Hemodynamic characteristics}

Pheochromocytoma patients have hemodynamic features similar to patients with essential hypertension. Thus, increased peripheral vascular resistance seems to be primarily responsible for maintenance of hypertension (Bravo \& Tagle, 2003).

\section{Diagnosis}

Before discussing the role of laboratory diagnosis and research of imaging methods would be interesting to present the patient with symptoms of pheochromocytoma and the reasons would lead to further investigation. The table 1 shows the main points of clinical presentation for screening of pheochromocytoma. In addition, the table 2 shows the main differential diagnosis (Young \& Sheps, 2008).

\begin{tabular}{|l|}
\hline Episodic symptoms of headaches, tachycardia, and diaphoresis \\
\hline $\begin{array}{l}\text { Remember the five “ } \mathrm{H}^{\prime} \text { characterizing pheochromocytoma: hypertension, } \\
\text { hyperglycemia, hypermetabolism, hyperhidrosis and headache }\end{array}$ \\
\hline $\begin{array}{l}\text { Family history of pheochromocytoma or a MEN syndrome, VHL, or neurofibromatosis } \\
\text { type } 1\end{array}$ \\
\hline Incidental adrenal or abdominal masses \\
\hline $\begin{array}{l}\text { Unexplained paroxysms of tachyarrhythmias, bradyarrhythmias and / or hypertension } \\
\text { during intubation, induction of anesthesia, parturition, or prolonged and unexplained } \\
\text { hypotension after an operation }\end{array}$ \\
\hline $\begin{array}{l}\text { Adverse cardiovascular responses to ingestion, inhalation or injection of certain drugs } \\
\text { (anesthetic agents, histamine, glucagons, naloxone, antidopaminergic agents, tricyclic } \\
\text { antidepressants) }\end{array}$ \\
\hline Attacks occurring during exertion, turning the torso, coitus, or micturition. \\
\hline
\end{tabular}

Table 1. Patients for screening of pheochromocytoma. 


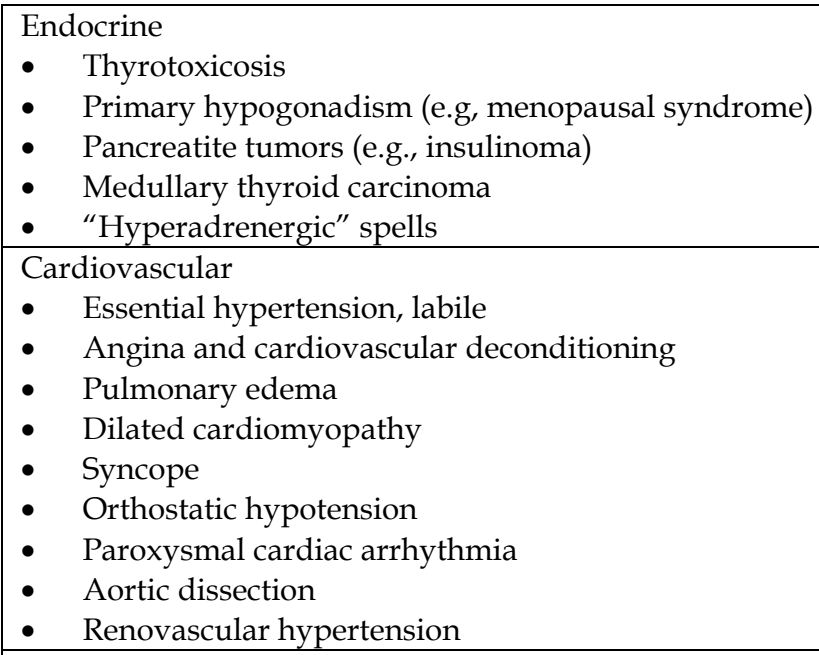

Psychological

- Anxiety and panic attacks

- Somatization disorder

- Hyperventilation

- $\quad$ Factitious (e.g., drugs, Valsalva)

Pharmacologic

- Withdrawal of adrenergic-inhibiting medication (e.g, clonidine)

- Monoamine oxidase inhibitor treatment and concomitante ingestion of tyramine or a decongestant

- Sympathomimetic ingestion

- $\quad$ Ilicit drug ingestion (e.g, cocaine, phencyclidine, lysergic acid)

- Acrodynia (Mercury poisoning)

- Vancomycin (red man syndrome)

Neurologic

- Baroreflex failure

- Postural orthostatic tachycardia syndrome

- Autonomic neuropathy

- Migraine headache

- Diencephalic epilepsy (autonomic seizures)

- Cerebral infarction

- Cerebrovascular insufficiency

Miscellaneous

- Mastocytosis (systemic or activation disorder)

- Carcinoid syndrome

- Recurrent idiopathic anaphylaxis

- Unexplained flushing spells

Table 2. Differential diagnosis of pheochromocytoma. 
Approximately $50 \%$ of pheochromocytomas produce excessive amounts $\mathrm{E}$ and NE and the other $50 \%$ predominantely produce NE. Sympathetic paragangliomas produce mainly NE, frequently dopamine, and never E (Eisenhofer et al., 2003).

Measurements of fractionated metanephrines in urine and in plasma or both are the initial testing for pheochromocytoma (Lenders et al., 2002) and no single analysis can achieve $100 \%$ accuracy for pheochromocytoma diagnosis.

When the presence of a pheochromocytoma appears likely but with equivocal biochemical testing, a clonidine test is recommended to distinguish true from false positives results (Eisenhofer et al., 2003).

Levels of normetanephrine, metanephrine, or both metabolites are increased in almost all patients with pheochromocytoma. However, in small or microscopic tumors $(<1 \mathrm{~cm})$ producing small amounts of catecholamines, the levels of normetanephrine and metanephrine might be normal (Eisenhofer et al., 1999; Lenders et al., 2002). If there is a hereditary predisposition or a previous history for pheochromocytoma, a testing at a later date remains mandatory. False-negative results also could include patients with pheochromocytoma that do not produce NE or E, a more rare exception (Sawka et al., 2003).

\subsection{Plasma metanephrines}

Normal plasma levels of normetanephrine and metanephrine exclude pheochromocytoma, and no immediate testing for the tumor should be necessary. Thus, measurements of plasma free metanephrines eliminate false-negative in the diagnosis of pheochromocytoma. In contrast, false-positive results remain a common problem, potentially time-consuming and expensive for follow-up. Plasma free metanephrines sensitivity is $99 \%$, followed closely by urinary fractionated metanephrines at $97 \%$ (Lenders et al., 2002). The blood sample should be obtained in the supine position. The technique involves the determination of free metanephrines in plasma by high-performance liquid chromatography (HPLC). An elevation of at least four times the upper reference intervals is associated with nearly a $100 \%$ probability of pheochromocytoma or sympathetic paraganglioma (Lenders et al., 2005). Elevated catecholamine and metanephrine levels by one to three times the upper limits of normality are usually due to various medications or physiological responses. For tests of plasma free metanephrines the specificity is $89 \%$ (Bravo \& Tagle, 2003).

False-positive results include medical conditions, medications, inappropriate sampling conditions, and diet. An overnight fast and resting supine before blood sampling minimize the problem. Phenoxybenzamine and tricyclic antidepressants accounted for up to $45 \%$ of false-positive elevations of plasma or urinary norepinephrine and normetanephrine (Eisenhofer et al., 2003). However, selective serotonin reuptake inhibitors may provide an alternative medication because they are not a cause of false-positive results.

Phenoxybenzamine is a nonspecific a-adrenoreceptor blocker, causing norepinephrine and normetanephrine elevation by attenuating $\mathrm{a}_{2}$-adrenoreceptor-mediated feedback inhibition of norepinephrine release, possibly combined with reflexive sympathetic activation. Thus, this drug should be avoided until biochemical testing is complete. Alternative medications for blood pressure control may include calcium channel blockers and selective $\mathrm{a}_{1^{-}}$ adrenoreceptor blockers such as doxazosin and prazosin. Non-selective a-adrenoreceptor blockers were associated with $60 \%$ of all false-positive elevations of plasma metanephrine. Nevertheless, the false-positive rate was not high (12.5\%). Only if an equivocal result has been obtained, it is necessary repeat testing after withdrawing these medications. 


\subsection{Urinary free catecholamines and metabolites}

Urinary free NE and E and two major metabolites of the catecholamines, metanephrines (normetanephrines and metanephrines) and vanillylmandelic acid (VMA) are relatively easy to perform and are usually readly available. A diagnosis can be confirmed or excluded on the basis of properly collected 24h urine samples (Mannelli, 1989). In MEN syndromes, either 24-h urinary excretion or the calculated ratio of $\mathrm{E}$ to $\mathrm{NE}$ is a very sensitive screening test (Gagel et al, 1988). The sensitivity of the tests used to detect pheochromocytoma is as follows: urinary NE 86\%, urinary E 33\%, urinary VMA 64\%, plasma NE 58\%, and plasma E $33 \%$. Among all tests for pheochromocytoma, the higher specificities are $95 \%$ for test of urinary VMA and $93 \%$ for test of urinary total metanephrines (Bravo \& Tagle, 2003). The table 3 shows the sensitivity and specificity values of diagnostic tests.

\begin{tabular}{|l|c|c|c|c|}
\hline \multirow{2}{*}{} & \multicolumn{2}{|c|}{$\begin{array}{c}\text { Sensitivity \% } \\
\text { Hereditary }\end{array}$} & \multicolumn{2}{c|}{$\begin{array}{c}\text { Specificity \% } \\
\text { Sereditary }\end{array}$} \\
\hline Plasma & \multicolumn{5}{|c|}{} \\
\hline Free Metanephradic & \\
\hline Catecholamines & 97 & 99 & 96 & 72 \\
\hline Urine & 69 & 92 & 89 & 45 \\
\hline Metanephrines & 96 & 97 & 82 & 75 \\
\hline Catecholamines & 79 & 91 & 96 & 89 \\
\hline Total Metanephrines & 60 & 88 & 97 & 86 \\
\hline Vanilmandelic acid & 46 & 77 & 99 & \\
\hline
\end{tabular}

Table 3. The sensitivity and specificity values of diagnostic tests.

\subsection{Patterns of biochemical test results}

Patients with pheochromocytoma usually have larger relative increases in metanephrines than catecholamines, whereas patients with false-positive results due sympathoadrenal activation usually have larger increases in catecholamines than metanephrines. These differences are possible because pheochromocytoma tumor cells produce metanephrines continuously and release into the circulation independently of variations in release of the parent catecholamines (Eisenhofer et al., 1998).

A plasma normetanephrine to NE ratio above 0.52 or a metanephrine to E ratio above 4.2 can provide confirmatory evidence of pheochromocytoma in up to $30 \%$ of patients where increases in plasma metanephrines are insufficient to prove the tumor (Eisenhofer et al., 2003).

\subsection{Clonidine-suppression testing}

This test was introduced by Bravo et al. (Bravo et al., 1981) to distinguish patients with pheochromocytoma from those with false-positive biochemical results. Decreases in elevated NE concentrations after clonidine suggest sympathetic activation, whereas a lack of decrease suggests pheochromocytoma. However, normal suppression occurs and this test is recommended for patients with plasma catecholamine levels over $1000 \mathrm{ng} /$ liter (5.9 
nmol/liter), with a normal response defined as a fall to within normal range (Bravo \& Gifford, 1984).

Another criterion for a normal response has been a fall in plasma NE after clonidine of more than $50 \%$ in patients with normal or only mildly elevated plasma NE levels (Bravo \& Tagle, 2003). Plasma normetanephrine is better than NE as end-point marker for the clonidine-supression test, because pheochromocytomas cause larger, more consistent, and less episodic increases of plasma normetanephrine than NE. $76 \%$ of plasma normetanephrine is derived from NE released by sympathetic nerves while $90 \%$ of circulating metanephrine is normally derived from metabolism of $\mathrm{E}$ within adrenal chromaffin cells. Lack of decrease of plasma normetanephrine combined with a high plasma level after clonidine establishes high probability of pheochromocytoma. Plasma normetanephrine concentrations remained elevated after clonidine in $96 \%$ of patients with pheochromocytoma compared with only $67 \%$ for NE. (Bravo et al., 1981; Eisenhofer et al., 2003).

\subsection{Imaging}

Computed tomography (CT) and magnetic resonance imaging (MRI) are sensitive studies and are recommended for initial tumor localization. MRI is preferred for children, pregnant or lactating women, anyone who expresses concern about excessive radiation exposure, and individuals who have had previous surgical resection in abdominal, pelvic, and thoracic cavities. The tumor diameter in majority of pheochromocytomas is greater than $2 \mathrm{~cm}$, thus it is possible diagnose them by CT. The CT sensibility for pheochromocytoma diagnosis is about $90 \%$. However, CT is less sensitive in small tumors. The MRI has a sensibility of $95 \%$ for the adrenal tumor bigger than $0.5 \mathrm{~cm}$ (Timmers et al., 2009).

Functional imaging agents that target the catecholamine synthesis, storage, and secretion pathways of chromaffin tumor cells are currently used. These techniques include 123/131 metaiodobenzylguanidine (MIBG) scintigraphy, 6-[18F]fluoro-L-3,4-dihydroxyphenylalanine (DOPA) positron emission tomography (PET), and 6-[18F]fluorodopamine (FDA) PET. Another modality for localization of metastatic paraganglioma is the 2 -[18F]fluoro-2-deoxyD-glucose (FDG) PET, that is less tissuspecific than the other functional approaches (Timmers et al., 2009).

The 123I-metaiodobenzylguanidine (MIBG) scan has better specificity than CT and MRI, however it is less sensitive in the context of familial paraganglioma syndrome, paragangliomas, and metastatic disease. ${ }^{123}$ I-MIBG is preferred over ${ }^{131}$ I-MIBG because of its higher sensitivity, lower radiation exposure, and improved imaging quality with singlephoton emission-computed tomography (Timmers et al., 2009). Previous studies suggest a sensitivity of ${ }^{123}$ I-MIBG scintigraphy of $92-98 \%$ for nonmetastatic paraganglioma and $57-79 \%$ for metastases (Van Der Horst-Schrivers et al., 2006). Recently a study confirmed that the sensitivity is high for primary tumors and relatively poor (50\%) for metastases (Timmers et al., 2009).

Non-metastatic paragangliomas are well localized by these techniques described previously according to Timmers and collaborators (Timmers et al., 2009). However, for the detection of metastases seen on CT, ${ }^{18} \mathrm{~F}-\mathrm{FDA}-\mathrm{PET}$ was superior to ${ }^{18} \mathrm{~F}-\mathrm{DOPA}-\mathrm{PET}$ and ${ }^{123} \mathrm{I}-\mathrm{MIBG}$ scanning. ${ }^{18} \mathrm{~F}-\mathrm{FDG}-\mathrm{PET}$ is superior in evaluating metastatic paraganglioma with mutations in succinate dehydrogenase subunit B (SDHB), whereas ${ }^{18}$ F-DOPA-PET performs best in non-SDHB patients (Timmers et al., 2007). The figure 1 shows the algorithm for biochemical and radiological diagnosis of pheochromocytoma. 


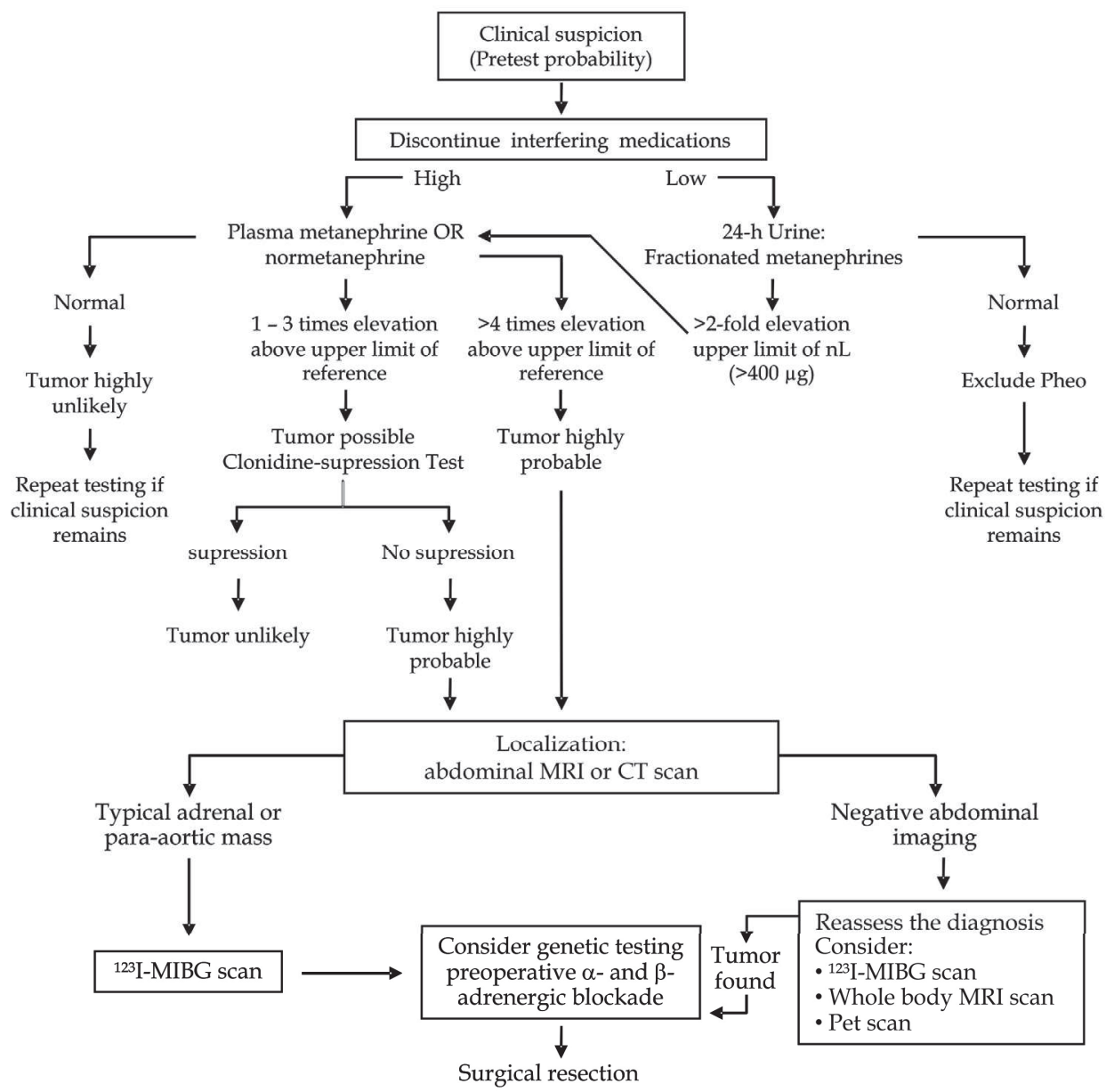

Fig. 1. The algorithm for biochemical and radiological diagnosis of pheochromocytoma.

\subsection{Genetics}

In actuality, $17-35 \%$ of pheochromocytomas and paragangliomas have a hereditary background. These hereditary tumors have been described in patients with neurofibromatosis type 1 (NF1), von Hippel Lindau syndrome (VHL), multiple endocrine neoplasia type 2 (MEN 2), and paraganglioma/ pheochromocytoma syndromes types 1-4 (PGL1, PGL2, PGL3, and PGL4) (Gill et al., 2011). The mutated genes are, respectively, NF1, VHL, RET proto-oncogene (Rearranged in Transfection), and subunits of the enzyme succinate dehydrogenase (SDHD, SDH5, SDHC, and SDHB) (Gimenez-Roqueplo et al., 2003). Hereditary pheochromocytomas and paragangliomas can be found at any age. However, most of these tumors are diagnosed in people younger than 50 years of age (Eisenhofer et al., 2011a). The most prevalent among these syndromes is PGL 1, caused 
by germline SDHD mutations, followed by PGL 4, whereas PGL 3 is rare (Amar et al., 2005).

The genetic screening should be considered in patients with history for paraganglial tumors, multiple tumors, young age at diagnosis, malignant pheochromocytoma because the prognosis in carriers of SDHB mutations is worse compared with non-SDHB-positive ones (Jiménez et al., 2006). Identification of a patient as a carrier of a germline mutation should be as early as possible. Mutation analysis of NF1 gene is not indicated because patients who have pheochromocytoma and carry this gene mutation also have neurofibromas or other signs of the syndrome. In general, patients presenting with pheochromocytoma who have MEN 2 and a RET mutation will have a personal or family history of MEN 2 features (Eisenhofer et al., 2011b). Mutations of VHL, NF 1 and RET genes are rare. Therefore, mutation analysis of VHL, RET, and NF 1 should not be performed unless there is clear clinical evidence of these syndromic features in the patient and/or family (Neumann \& Eng, 2010).

The pathological examination of surgically resected or biopsied tumor tissue or a diagnosis of inoperable malignant pheochromocytoma based on findings of metastatic disease by imaging studies is required to confirm pheochromocytoma.

\section{References}

Amar, L.; Bertherat, J.; Baudin, E, Ajzenberg, C.; Bressac-de Paillerets, B.; Chabre, O.; Chamontin, B.; Delemer, B.; Giraud, S.; Murat, A.; Niccoli-Sire, P.; Richard, S.; Rohmer, V.; Sadoul, J.L.; Strompf, L.; Schlumberger, M.; Bertagna, X.; Plouin, PF.; Jeunemaitre, X. \& Gimenez-Roqueplo, A.P. (2005). Genetic testing in pheochromocytoma or functional paraganglioma. J Clin Oncol. Vol.23, No. 34, (December 2005), pp. 8812-8. ISSN: 0732-183X.

Beard, C.M.; Sheps, S.G.; Kurland, L.; Carney, J.A. \& Lie, J.T. (1983). Occurrence of pheochromocytoma in Rochester, Minnesota, 1950 through 1979. Mayo Clin Proc. Vol. 58, No. 12, (December 1983), pp. 802-4. ISSN: 0025-6196.

Bravo, E.L.; Tarazi, R.C.; Gifford, R.W. \& Stewart, B.H. (1979). Circulating and urinary catecholamines in pheochromocytoma. Diagnostic and pathophysiologic implications. N Engl J Med. Vol. 301, No. 13, (September 1979), pp. 682-6. ISSN: 0028-4793.

Bravo, E.L.; Tarazi, R.C.; Fouad, F.M.; Textor, S.C.; Gifford, R.W. Jr. \& Vidt, D.G. (1982). Blood pressure regulation in pheochromocytoma. Hypertension. Vol. 4, No. $3 \mathrm{Pt} 2$, (May-June 1982), pp. 193-9. ISSN: 0194-911X.

Bravo, E.L. \& Tagle, R. (2003). Pheochromocytoma: state-of-the-art and future prospects. Endocr Rev. Vol. 24, No. 4, (August 2003), pp. 539-53. ISSN: 0163-769X.

Bravo, E.L., Tarazi, R.C.; Fouad, F.M.; Vidt, D.G. \& Gifford, R.W. Jr. (1981). Clonidinesuppression test: a useful aid in the diagnosis of pheochromocytoma. $N$ Engl J Med. Vol. 305, No. 11, (September 1981), pp. 623-6. ISSN: 0028-4793.

Bravo, E.L. \& Gifford, R.W. Jr. (1984). Current concepts. Pheochromocytoma: diagnosis, localization and management. N Engl J Med. Vol. 311, No. 20, (November 1984), pp. 1298-303. ISSN: 0028-4793. 
Cascón, A.; Pita, G.; Burnichon, N.; Landa, I.; López-Jiménez, E.; Montero-Conde, C.; Leskelä, S.; Leandro-García, L.J.; Letón, R.; Rodríguez-Antona, C.; Díaz, J.A.; LópezVidriero, E.; González-Neira, A.; Velasco, A.; Matias-Guiu, X.; Gimenez-Roqueplo, A.P. \& Robledo, M. (2009). Genetics of pheochromocytoma and paraganglioma in Spanish patients. J Clin Endocrinol Metab. Vol. 94, No. 5, (May 2009), pp. 1701-5. ISSN: 0021-972X.

deS Senanayake, P.; Denker, J.; Bravo, E.L. \& Graham, R.M. (1995). Production, characterization, and expression of neuropeptide $\mathrm{Y}$ by human pheochromocytoma. J Clin Invest. Vol. 96, No. 5, (November 1995), pp. 2503-9. ISSN: 00219738.

Eisenhofer, G.; Goldstein, D.S.; Walther, M.M.; Friberg, P.; Lenders, J.W.; Keiser, H.R. \& Pacak, K. (2003). Biochemical diagnosis of pheochromocytoma: how to distinguish true- from false-positive test results. J Clin Endocrinol Metab. Vol. 88, No. 6, (June 2003), pp. 2656-66. ISSN: 0021-972X.

Eisenhofer, G.; Keiser, H.; Friberg, P.; Mezey, E.; Huynh, T.T.; Hiremagalur, B.; Ellingson, T.; Duddempudi, S.; Eijsbouts, A. \& Lenders, J.W. (1998). Plasma metanephrines are markers of pheochromocytoma produced by catechol-O-methyltransferase within tumors. J Clin Endocrinol Metab. Vol. 83, No. 6, (June 1998), pp. 2175-85. ISSN: 0021972X.

Eisenhofer, G.; Lenders, J.W.; Linehan, W.M.; Walther, M.M.; Goldstein, D.S. \& Keiser, H.R. (1999). Plasma normetanephrine and metanephrine for detecting pheochromocytoma in von Hippel-Lindau disease and multiple endocrine neoplasia type 2. N Engl J Med. Vol. 340, No. 24, (June 1999), pp. 1872-9. ISSN: 00284793.

Eisenhofer, G.; Timmers, H.J.; Lenders, J.; Bornstein, S.R.; Tiebel, O.; Mannelli, M.; King, K.S.; Vocke, C.D.; Linehan, W.M.; Bratslavsky, G. \& Pacak, K. (2011). Age at diagnosis of pheochromocytoma differs according to catecholamine phenotype and tumor location. J Clin Endocrinol Metab. Vol. 96, No. 2, (February 2011), pp. 375-84. ISSN: 0021-972X.

Eisenhofer, G.; Lenders, J.W.; Timmers, H.; Mannelli, M.; Grebe, S.K.; Hofbauer, L.C.; Bornstein, S.R.; Tiebel, O.; Adams, K.; Bratslavsky, G.; Linehan, W.M. \& Pacak, K. (2011). Measurements of plasma methoxytyramine, normetanephrine, and metanephrine as discriminators of different hereditary forms of pheochromocytoma. Clin Chem. Vol. 57, No. 3, (March 2011), pp. 411-20. ISSN: 0009-9147.

Erickson, D.; Erickson D, Kudva, Y.C.; Ebersold, M.J.; Thompson, G.B.; Grant, C.S.; van Heerden, J.A. \& Young, W.F. Jr. (2001). Benign paragangliomas: clinical presentation and treatment outcomes in 236 patients. J Clin Endocrinol Metab. Vol. 86, No. 11, (November 2001), pp. 5210-6. ISSN: 0021-972X.

Gagel, R.F.; Tashjian, A.H. Jr; Cummings, T.; Papathanasopoulos, N.; Kaplan, M.M.; DeLellis, R.A.; Wolfe, H.J. \& Reichlin, S. (1988). The clinical outcome of prospective screening for multiple endocrine neoplasia type 2a. An 18-year experience. $N$ Engl J Med. Vol. 318, No. 8, (February 1988), pp. 478-84. ISSN: 0028-4793. 
Gill, A.J.; Pachter, N.S.; Clarkson, A.; Tucker, K.M.; Winship, I.M.; Benn, D.E.; Robinson, B.G. \& Clifton-Bligh, R.J. (2011). Renal tumors and hereditary pheochromocytomaparaganglioma syndrome type 4. N Engl J Med. Vol. 364, No. 9, (March 2011), pp. 885-6. ISSN: 0028-4793.

Gimenez-Roqueplo, A.P.; Favier, J.; Rustin, P.; Rieubland, C.; Crespin, M.; Nau, V.; Khau Van Kien, P.; Corvol, P.; Plouin, P.F.; Jeunemaitre, X. \& COMETE Network. (2003). Mutations in the SDHB gene are associated with extra-adrenal and/or malignant phaeochromocytomas. Cancer Res. Vol. 63, No. 17, (September 2003), pp. 5615-21. ISSN: 0008-5472.

Golden, S.H.; Robinson, K.A.; Saldanha, I.; Anton, B. \& Ladenson, P.W. (2009). Clinical review: Prevalence and incidence of endocrine and metabolic disorders in the United States: a comprehensive review. J Clin Endocrinol Metab. Vol. 94, No. 6, (June 2009), pp. 1853-78. ISSN: 0021-972X.

Guerrero, M.A.; Schreinemakers, J.M.; Vriens, M.R.; Suh, I.; Hwang, J.; Shen, W.T.; Gosnell, J.; Clark, O.H. \& Duh, Q.Y. (2009). Clinical spectrum of pheochromocytoma. J Am Coll Surg. Vol. 209, No. 6, (December 2009), pp. 727-32. ISSN: 1072-7515.

Jiménez, C. (2010). A current review of the etiology, diagnosis, and treatment of pediatric pheochromocytoma and paraganglioma. J Clin Endocrinol Metab. Vol. 95, No. 5, (May 2010), pp. 2023-37. ISSN: 0021-972X.

Jiménez, C.; Cote, G.; Arnold, A. \& Gagel, R.F. (2006). Review: Should patients with apparently sporadic pheochromocytomas or paragangliomas be screened for hereditary syndromes? J Clin Endocrinol Metab. Vol. 91, No. 8, (August 2006), pp. 2851-8. ISSN: 0021-972X.

Kopetschke, R.; Slisko, M.; Kilisli, A.; Tuschy, U.; Wallaschofski, H.; Fassnacht, M.; Ventz, M.; Beuschlein, F.; Reincke, M.; Reisch, N. \& Quinkler, M. (2009). Frequent incidental discovery of phaeochromocytoma: data from a German cohort of 201 phaeochromocytoma. Eur J Endocrinol. Vol. 161, No. 2, (August 2009), pp. 355-61. ISSN: 0804-4643.

Kudva, Y.C.; Sawka, A.M. \& Young, W.F Jr. (2003). Clinical review 164: The laboratory diagnosis of adrenal pheochromocytoma: the Mayo Clinic experience. J Clin Endocrinol Metab. Vol. 88, No. 10, (October 2003), pp. 4533-9. ISSN: 0021972X.

Lenders, J.W.; Pacak, K.; Walther, M.M.; Linehan, W.M.; Mannelli, M.; Friberg, P.; Keiser, H.R.; Goldstein, D.S. \& Eisenhofer, G. (2002). Biochemical diagnosis of pheochromocytoma: which test is best? JAMA. Vol. 287, No. 11, (March 2002), pp. 1427-34. ISSN: 0098-7484.

Lenders, J.W.; Eisenhofer, G.; Mannelli, M. \& Pacak, K. (2005). Phaeochromocytoma. Lancet. Vol. 366, No. 9486, (August 2005), pp. 665-75. ISSN: 0140-6736.

Lundberg, J.M.; Hökfelt, T.; Hemsén. A.; Theodorsson-Norheim, E.; Pernow, J.; Hamberger, B. \& Goldstein, M. (1986). Neuropeptide Y-like immunoreactivity in adrenaline cells of adrenal medulla and in tumors and plasma of pheochromocytoma patients. Regul Pept. Vol 13, No. 2, (January 1986), pp. 169-82. ISSN: 0167-0115.

Lundberg, J.M. \& Tatemoto, K. (1982). Pancreatic polypeptide family (APP, BPP, NPY and PYY) in relation to sympathetic vasoconstriction resistant to alpha-adrenoceptor 
blockade. Acta Physiol Scand. Vol. 116, No. 4, (December 1982), pp. 393-402. ISSN: 1748-1708.

Madani, R.; Al-Hashmi, M.; Bliss, R. \& Lennard, T.W. (2007). Ectopic pheochromocytoma: does the rule of tens apply? World J Surg. Vol. 31, No. 4, (April 2007), pp. 849-54. Erratum in: World J Surg. Vol. 32, No. 2, (February 2008), pp. 334. ISSN: 03642313.

Mannelli, M. (1989). Diagnostic problems in pheochromocytoma. J Endocrinol Invest. Vol. 12, No. 10, (November 1989), pp. 739-57. ISSN: 0391-4097.

Mannelli, M.; Castellano, M.; Schiavi, F.; Filetti, S.; Giacchè, M.; Mori, L.; Pignataro, V.; Bernini, G.; Giachè, V.; Bacca, A.; Biondi, B.; Corona, G.; Di Trapani, G.; Grossrubatscher, E.; Reimondo, G.; Arnaldi, G.; Giacchetti, G.; Veglio, F.; Loli, P.; Colao, A.; Ambrosio, M.R.; Terzolo, M.; Letizia, C.; Ercolino, T. \& Opocher, G. Italian Pheochromocytoma/Paraganglioma Network. (2009). Clinically guided genetic screening in a large cohort of italian patients with pheochromocytomas and/or functional or nonfunctional paragangliomas. J Clin Endocrinol Metab. Vol. 94, No. 5, (May 2009), pp. 1541-7. ISSN: 0021-972X.

McNeil, A.R.; Blok, B.H.; Koelmeyer, T.D.; Burke, M.P.; \& Hilton, J.M. (2000). Phaeochromocytomas discovered during coronial autopsies in Sydney, Melbourne and Auckland. Aust N Z J Med. Vol. 30, No. 6, (December 2000), pp. 648-52. ISSN: 0004-8291.

Neumann, H.P.; Bausch, B.; McWhinney SR.; Bender, B.U.; Gimm, O.; Franke, G.; Schipper, J.; Klisch, J.; Altehoefer, C.; Zerres, K.; Januszewicz, A.; Eng, C.; Smith, W.M.; Munk, R.; Manz, T.; Glaesker, S.; Apel, T.W.; Treier, M.; Reineke, M.; Walz, M.K.; Hoang-Vu, C.; Brauckhoff, M.; Klein-Franke, A.; Klose, P.; Schmidt, H.; MaierWoelfle, M.; Peçzkowska, M.; Szmigielski, C.; Eng, C. \& Freiburg-WarsawColumbus. Pheochromocytoma Study Group. (2002). Germ-line mutations in nonsyndromic pheochromocytoma. N Engl J Med. Vol. 346, No. 19, (May 2002), pp. 1459- 66. ISSN: 0028-4793.

Neumann, H.P.H. \& Eng, C. (2010). Management of paraganglioma, In: A Clinical Approach to Endocrine Metabolic Diseases. Ladenson P.W. pp. 197-208. The Endocrine Society, ISBN: 1-879225-70-0, Chevy Chase, Maryland

O'Hare, M. \& Schwartz, T.W. (1989). Expression and precursor processing of neuropeptide Y in human pheochromocytoma and neuroblastoma tumors. Cancer Res. Vol. 49, No. 24 Pt 1, (December 1989), pp. 7010-4. ISSN: 0008-5472.

Omura, M.; Saito, J.; Yamaguchi, K.; Kakuta, Y. \& Nishikawa, T. (2004). Prospective study on the prevalence of secondary hypertension among hypertensive patients visiting a general outpatient clinic in Japan. Hypertens Res. Vol. 27, No. 3, (March 2004), pp. 193-202. ISSN: 0916-9636.

Perel, Y.; Schlumberger, M.; Marguerite, G.; Alos, N.; Revillon, Y.; Sommelet, D.; De Lumley, L.; Flamant, F.; Dyon, J.F.; Lutz, P.; Heloury, H. \& Lemerle, J. (1997). Pheochromocytoma and paraganglioma in children: a report of 24 cases of the French Society of Pediatric Oncology. Pediatr Hematol Oncol. Vol. 14, No. 5, (September-October 1997), pp. 413-22. ISSN: 1077-4114. 
Sawka, A.M.; Jaeschke, R.; Singh, R.J. \& Young, W.F. Jr. (2003). A comparison of biochemical tests for pheochromocytoma: measurement of fractionated plasma metanephrines compared with the combination of 24-hour urinary metanephrines and catecholamines. J Clin Endocrinol Metab. Vol. 88, No. 2, (February 2003), pp. 553-8. ISSN: 0021-972X.

Shen, W.T.; Grogan, R.; Vriens, M.; Clark, O.H. \& Duh, Q.Y. (2010). One hundred two patients with pheochromocytoma treated at a single institution since the introduction of laparoscopic adrenalectomy. Arch Surg. Vol. 145, No. 9, (September 2010), pp. 893-7. ISSN: 0004-0010.

Smythe, G.A.; Edwards, G.; Graham, P. \& Lazarus, L. (1992). Biochemical diagnosis of pheochromocytoma by simultaneous measurement of urinary excretion of epinephrine and norepinephrine. Clin Chem. Vol. 38, no. 4, (April 1992), pp. 486-92. ISSN: 0009-9147.

Stenström, G \& Svärdsudd, K. (1986). Pheochromocytoma in Sweden 1958-1981. (1986). An analysis of the National Cancer Registry Data. Acta Med Scand. Vol. 220, No. 3, (1986), pp. 225-32. ISSN: 0003-9926

Suh, I.; Shibru, D.; Eisenhofer, G.; Pacak, K.; Duh, Q.Y.; Clark, O.H. \& Kebebew, E. (2009). Candidate genes associated with malignant pheochromocytomas by genome-wide expression profiling. Ann Surg. Vol. 250, No. 6, (December 2009), pp. 983-90. ISSN: 0003-4932.

Timmers, H.J.; Chen, C.C.; Carrasquillo, J.A.; Whatley, M.; Ling, A.; Havekes, B.; Eisenhofer, G.; Martiniova, L.; Adams, K.T. \& Pacak, K. (2009) Comparison of 18F-fluoro-LDOPA, 18F-fluoro-deoxyglucose, and 18F-fluorodopamine PET and 123I-MIBG scintigraphy in the localization of pheochromocytoma and paraganglioma. J Clin Endocrinol Metab. Vol. 94, No.12 (December 2009), pp. 4757-67. ISSN: 0021$972 X$.

Timmers, H.J.; Kozupa, A.; Chen, C.C.; Carrasquillo, J.A.; Ling, A.; Eisenhofer, G.; Adams, K.T.; Solis, D.; Lenders, J.W. \& Pacak, K. (2007). Superiority of fluorodeoxyglucose positron emission tomography to other functional imaging techniques in the evaluation of metastatic SDHB-associated pheochromocytoma and paraganglioma. J Clin Oncol. Vol. 25, No. 16, (June 2007), pp. 2262-9. ISSN: 0732-183X.

Van Der Horst-Schrivers, A.N.; Jager, P.L.; Boezen, H.M.; Schouten, J.P.; Kema, I.P. \& Links, T.P. (2006). Iodine-123 metaiodobenzylguanidine scintigraphy in localizing phaeochromocytomas--experience and meta-analysis. Anticancer Res. Vol. 26, No. 2B, (March-April 2006), pp. 1599-604. ISSN: 0250-7005.

Van Der Horst-Schrivers, A.N.; Osinga, T.E.; Kema, I.P.; Van Der Laan, B.F. \& Dullaart, R.P. (2010). Dopamine excess in patients with head and neck paragangliomas. Anticancer Res. Vol. 30, No. 12, (December 2010), pp. 5153-8. ISSN: 02507005.

Villar, J.M.; Moreno, P.; Ortega, J.; Bollo, E.; Ramírez, C.P.; Muñoz, N.; Martínez, C.; Domínguez-Adame, E.; Sancho, J.; del Pino, J.M.; Couselo, J.M.; Carrión, A.; Candel, M.; Cáceres, N.; Octavio, J.M.; Mateo, F.; Galán, L.; Ramia, J.M.; Aguiló, J. \& Herrera, F. (2010). Results of adrenal surgery. Data of a Spanish National Survey. 
Langenbecks Arch Surg. Vol. 395, No. 7, (September 2010), pp. 837-43. ISSN: 14352443.

Young, W.F. \& Sheps, S.G. (2008). Management of Pheochomocytoma, In: Hypertension Prime. The Essentials of High Blood Pressure: Basic Science, population science, and clinical management. Joseph L Izzo Jr, Domenic A Sica, Henry R Black (eds) pp. 571573. Fourth Edition. Lippincott Williams \& Wilkins, American Heart Association, ISBN: 978-0-7817-8205-0. Dallas, Texas. 


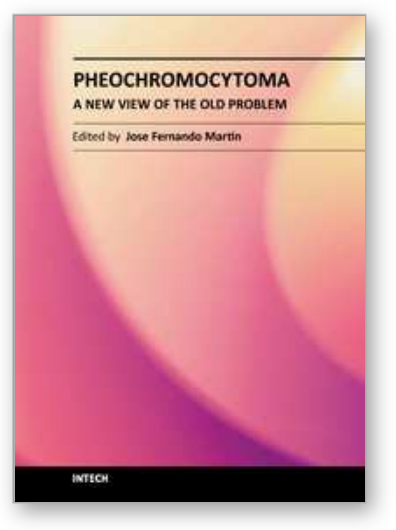

\author{
Pheochromocytoma - A New View of the Old Problem \\ Edited by Dr. Jose Fernando Martin
}

ISBN 978-953-307-822-9

Hard cover, 164 pages

Publisher InTech

Published online 16, December, 2011

Published in print edition December, 2011

The book is divided into six sections. The first three sections focus on the pathophysiology of the disease, showing anatomo- and histopathological aspects, experimental models and signaling pathways and programmed cell death related to pheochromocytoma. The fourth discusses some specific aspects of clinical presentation, with emphasis on clinical manifestations of headache and heart. The fifth section focuses on clinical diagnosis, laboratory and imaging, including differential diagnosis. Finally, the last section discusses the treatment of pheochromocytoma showing clinical cases, a case about undiagnosed pheochromocytoma complicated with multiple organ failure and other cases about catecholamine-secreting hereditary tumors. Thus, this book shows the disease "pheochromocytoma" in a different perspective from the traditional approach. Enjoy your reading.

\title{
How to reference
}

In order to correctly reference this scholarly work, feel free to copy and paste the following:

José Fernando Vilela-Martin and Luciana Neves Cosenso-Martin (2011). Diagnosis: Laboratorial Investigation and Imaging Methods, Pheochromocytoma - A New View of the Old Problem, Dr. Jose Fernando Martin (Ed.), ISBN: 978-953-307-822-9, InTech, Available from: http://www.intechopen.com/books/pheochromocytoma-anew-view-of-the-old-problem/diagnosis-laboratorial-investigation-and-imaging-methods

\section{INTECH}

open science | open minds

\author{
InTech Europe \\ University Campus STeP Ri \\ Slavka Krautzeka 83/A \\ 51000 Rijeka, Croatia \\ Phone: +385 (51) 770447 \\ Fax: +385 (51) 686166 \\ www.intechopen.com
}

\author{
InTech China \\ Unit 405, Office Block, Hotel Equatorial Shanghai \\ No.65, Yan An Road (West), Shanghai, 200040, China \\ 中国上海市延安西路65号上海国际贵都大饭店办公楼 405 单元 \\ Phone: +86-21-62489820 \\ Fax: +86-21-62489821
}


(C) 2011 The Author(s). Licensee IntechOpen. This is an open access article distributed under the terms of the Creative Commons Attribution 3.0 License, which permits unrestricted use, distribution, and reproduction in any medium, provided the original work is properly cited. 